\title{
FUNCTIONS OF CODE SWITCHING IN MULTILINGUAL CLASSROOMS
}

\author{
S Rose and O van Dulm \\ University of Stellenbosch
}

The research reported in this paper focuses on the functions of code switching between English and Afrikaans in the classroom interactions of a secondary school in the Western Cape. The data comprising audio recordings of classroom interactions are analysed within the framework of Myers-Scotton's (1993a) Markedness Model, according to which there are four types of code switching, namely marked, unmarked, sequential unmarked, and exploratory code switching. Within each of these types of code switching, a number of specific functions of code switching in the classrooms observed are identified, such as expansion, clarification, and identity marking. The study concludes that the Markedness Model offers a useful framework within which to analyse types of code switching, and that code switching has a specific functional role to play within multicultural and multilingual classrooms.

\section{INTRODUCTION}

Code switching is a widespread phenomenon in South Africa's multilingual and multicultural society. With eleven official languages, namely isiZulu, isiXhosa, isiNdebele, siSwati, seSotho, sePedi, seTswana, Tsonga, Tshivenda, English, and Afrikaans, as well as a number of other languages and varieties, there is widespread bilingualism. In this context, it is common practice for bilinguals to mix languages in their everyday conversations, and the phenomenon of code switching is often observed. Such code switching takes place in both intercultural communication and in communication among people of the same culture who share knowledge of more than one language. The term 'code switching' refers here to alternations of language within a single conversation, often involving switches within a single speaker turn or a single sentence. Code switching is distinguished here from a number of related phenomena which are common in bilingual conversation. Firstly, code switching is distinguished from borrowing, which entails 'the incorporation of lexical elements from one language in the lexicon of another language' (Muysken, 1995: 189). Some single word switches were included as data in the present study, but switched items which were recognised as established borrowings were excluded. A second distinction is that between code switching and interference, where interference is taken to entail 'the involuntary influence of one language on another' (Grosjean, 1984: 299), and so differs from code switching in that it is not a voluntary behaviour. Finally, a distinction may be made between code switching the use of a so-called 'mixed code' or 'mixed variety'. A number of participants in the present study may be argued to have such a mixed language in their repertoire, namely 'Kaaps' or 'Cape Afrikaans'. ${ }^{1}$ However, the data were limited to classroom interactions in which the use of a mixed code was not observed. 
Much of the code switching research carried out in South Africa focuses on code switching in the educational setting. Multilingual and multicultural classrooms are the norm in South Africa, even more so since the abolition in the 1990s of Apartheid policies which kept schools racially segregated. The present Language in Education Policy (Act 27 of 1996) aims, among other things, (i) 'to establish additive multilingualism as an approach to language in education'; (ii) 'to promote and develop all official languages'; and (iii) 'to redress the neglect of the historically disadvantaged languages in education'. Furthermore, the policy states that (i) the language of learning and teaching (LoLT) must be an official language; (ii) the learner (or parent in the case of a minor) must choose the LoLT and a school that offers that LoLT is obligated to admit the learner if there is place in the relevant grade; (iii) if no school in the area offers the desired LoLT, the learner may request the Education Department to make such provision; (iv) the school governing body (a democratically elected body of parents) must determine the LoLT of a new school, and stipulate how the school will promote multilingualism; and (v) all learners must pass at least two languages as subjects (i.e., a first language and a second language), one of which must be an official language (cf. Department of Education Language in Education Policy 1997 for full details). At present, provincial education departments are aiming at equipping schools to offer mother tongue education during (at least) the so-called 'foundation phase', the first three years of schooling. Access to such mother tongue education, however, is often problematic because of the limited number of teachers who had the necessary training to offer instruction in these languages, and the lack of teaching materials in languages other than English and Afrikaans. Instruction for the later primary school phase and for secondary school may or may not switch to English or Afrikaans, depending largely on geographical location, availability of teachers, and decisions made by the school governing body, among other factors.

The aim of code switching research in the educational setting in South Africa has been to identify the incidence and functions of code switching by teachers and learners. Such studies are important in highlighting the possible implications of code switching for education, especially in light of the fact that many children in South Africa are taught in a language that is not their mother tongue, and also in light of the desire of many parents to have their children educated in English, which is regarded as a prestige language, providing access to the international arena. Adendorff (1993), for example, reports on the functions and implications of Zulu-English code switching among Zulu-speaking teachers and their learners, noting that code switching between Zulu and English functions to fulfil social functions, such as signalling solidarity or authority and building relationships, as well as for academic purposes, such as reiteration, to ensure the adequate communication of content (Adendorff, 1993: 17). Adendorff (1993: 19) concludes that teachers should be encouraged to accept code switching as a sign of bilingual competence, affording speakers communicative power, and thus social power. Further research on code switching which underlines the necessity for teachers to be aware of the phenomenon and its functional aspects is reported by Kieswetter (1995), who explores the patterns of code switching between English, Zulu and Swazi among a group of high school learners in an urban English-medium school. Kieswetter (1995: 6, 59) notes that code switching is used as a dynamic conversational strategy which reflects learners' dual identities. Kieswetter (1995: 96) echoes the sentiments expressed by Adendorff (1993), suggesting that teachers need to recognise the dynamic nature of language and to allow for the influence of context in learners' language use. Teachers' awareness of code switching as a communicative tool is also the focus of Lawrence's $(1999,2001)$ study at a teacher's training college, where English-Afrikaans code switching is regarded as a strategy for effective communication among Afrikaans and Xhosa L1 speakers. Further research reported by Ncoko, Osman and Cockcroft (2000) focuses on Zulu-English code switching in a primary 
school, where the learners used code switching to fulfil a variety of social functions, such as expressing solidarity, defiance, desire for inclusion or exclusion, and neutrality (Ncoko et al., 2000: 232, 233, 237). Code switching was further observed to be used for reiteration and to ensure the adequate transfer of meaning (Ncoko et al., 2000: 233, 237). Ncoko et al. (2000: 231) conclude that code switching is the norm among school children, and point out its potential for use as a teaching strategy (Ncoko et al., 2000: 239) (cf. also Setati, Adler, Reed and Bapoo (2002) in this regard.) Finally, research on the role of Zulu-English code switching in the construction of identity by Zulu L1 students on the Westville campus of the University of KwaZulu-Natal is reported by Ramsay-Brijball (2003, 2004), who concludes that 'Zulu L1 speakers use Zulu-English code switching ... as a tool to define themselves and to express their aspirations' (Ramsay-Brijball, 2004: 151).

From the brief overview of the literature on code switching in the educational setting given above, it is clear that there is a strong feeling among researchers that code switching has a role to play in both academic and social interactions between and among school teachers and learners. Furthermore, there seems to be a need to educate teachers and teachers-in-training with regard to the phenomenon of code switching and the specific functions it fulfils in intercultural communication in the classroom. In order for such education to take place, detailed information is needed on the functions and implications of code switching between various languages in the educational setting. To this end, the present study focuses on code switching between English and Afrikaans in the multicultural and multilingual classrooms of a secondary school in the Western Cape. The study aims to identify specific functions of code switching. The data are analysed within the framework of Myers-Scotton's (1993a) Markedness Model, which accounts for four types of codeswitching (marked, unmarked, sequential unmarked, exploratory) in terms of the degree of markedness of various code choices during conversation. In addition to this analysis into types of code switching, a number of specific functions of code switching are identified, illustrated, and discussed.

The following section offers a brief exposition of Myers-Scotton's (1993a) Markedness Model, after which the methodology of the present study is set out. The results of the study are presented and discussed in the final section.

\section{MYERS-SCOTTON'S MARKEDNESS MODEL}

According to Myers-Scotton (1998: 18), there is more than one way of speaking in almost every speech community. No community is without at least two different speech styles, and in many communities, more than one language, and often more than one dialect of each language, is spoken. All linguistic codes or varieties come to have social and psychological associations in the speech community in which they are used. Given these associations, the use of a particular code is viewed in terms of the marked versus the unmarked opposition with reference to the extent its use matches community expectations for the interaction type. In other words, what community norms would predict is unmarked; what community norms would not predict is marked (Myers-Scotton, 1998: 5). The Markedness Model uses the marked versus unmarked distinction as a theoretical construct to explain the social and psychological motivations for making one code choice over another. According to the Markedness Model, speakers have a sense of markedness regarding the linguistic codes available for any interaction, and speakers select their code(s) based on the persona or/and the relationships which they wish to have in place. This sense of markedness is based on the socalled 'markedness metric', proposed by Myers-Scotton (1993a: 79-80) to form part of a 
speaker's communicative competence. A critical point is that, while the metric is considered to be a universal cognitive structure, it underlies a very particular ability - the ability to assess the markedness of codes is only developed in reference to a specific community, and so one can speak of the markedness of a particular code choice only in reference to a specific context in a specific community (Myers-Scotton, 1993a: 80). Markedness has a normative basis within the community, and therefore speakers know the consequences of making marked or unmarked choices, and can asses the potential costs and rewards of alternative choices (Myers-Scotton, 1993a: 75). A central premise of the Markedness Model is embodied in the so-called 'negotiation principle' (modelled after Grice's (1975) co-operative principle), according to which all code choices can ultimately be explained in terms of speaker motivations (Myers-Scotton, 1993a: 113).

A central theoretical construct used by Myers-Scotton (1993a, 1998) to distinguish levels of markedness of code choices is the rights and obligations (RO) set. The RO set comprises rights and obligations upon which a speaker-hearer can base his/her expectations in a given interactional setting (Myers-Scotton 1998: 23). The RO set accounts for codes of behaviour and norms that are established and then maintained in social communities, and the unmarked RO set for a given interaction type originates from salient situational features, such as age, sex, occupation, socio-economic status, and ethnic group (Myers-Scotton, 1998: 24). Speakerhearers use information from their experiences in daily interactions in their community, together with the markedness metric as a cognitive device, to arrive at readings of markedness. Firstly, they take the specific salient situational factors of a given community and interaction type into account and establish the perimeter of the unmarked RO set for a specific interaction setting. Secondly, they calculate the relative markedness of code choices to index the unmarked RO set (Myers-Scotton, 1998: 25).

The Markedness Model accounts for all instances of code switching as one of four complementary types, namely (i) unmarked code switching, (ii) sequential unmarked code switching, (iii) marked code switching, and (iv) exploratory code switching (Myers-Scotton, 1993a: 114). Firstly, speakers may engage in code switching as a sequence of unmarked choices in which codes are switched in order to index any change in the RO set (MyersScotton, 1993a: 114). Secondly, code switching itself may be the unmarked choice, for instance when code switching is the pattern which carries the desired communicative intention and indexes the expected RO set (Myers-Scotton, 1993a: 117). Thirdly, a speaker may engage in code switching as the marked choice, whereby s/he is said to 'disidentify' with the expected RO set, wishing to establish a new RO set as unmarked for a particular communicative exchange (Myers-Scotton, 1993a: 131). Finally, code switching may function as an exploratory choice, such as when the speaker is unsure of what is expected or optimal, and wishes to find out which code choice will match his/her desired RO set (Myers-Scotton, 1993a: 142). The data collected in the present study were analysed in terms of these four types of code switching, and a number of functions of code switching were identified. ${ }^{2}$

\section{METHODOLOGY}

\section{Participants}

The study was conducted in an all-girls 'former Model C' secondary school in the Western Cape, South Africa. The school accommodates learners from all over the Western-Cape in its boarding facilities, as well as drawing non-boarding learners from the predominantly white 
suburb in which it is situated. The learner body is thus multicultural as well as multilingual. The LoLT in the school is predominantly English, and although there is no policy of bilingual instruction, provision is also made for Afrikaans as LoLT because of the large number of Afrikaans first language (L1) teachers and learners who are employed by and attend the school, respectively. It was observed to be common practice to use both English and Afrikaans as the LoLT for any subject being taught to a multilingual classroom. Most of the learners were English L1 with Afrikaans or isiXhosa as a second language (L2), while some of the learners were Afrikaans or isiXhosa L1 with English as an L2. Their ages ranged between 14 and 16 years.

\section{Naturalistic data}

Data were collected by means of the observation and audio recording of communicative interactions during formal class time by one of the researchers. The learners and the teachers were not told what the study was about, nor were they told what was expected of them during the observations or audio recordings. This non-disclosure aimed to prevent any conscious codeswitching and to ensure that the teachers and the learners were relaxed and spontaneous in their conversations. Data were collected in five different classes of three different subjects, two Afrikaans (second language) classes, two Life Orientation classes and one Geography class. All five classes were observed by the researcher over a period of three weeks, and three audio recordings were made of each class. The data were orthographically transcribed and then analysed in terms of types and functions of code switching.

\section{RESULTS AND DISCUSSION}

The results of the study are discussed below in sections corresponding to the types of code switching identified in accordance with Myers-Scotton's (1993a) Markedness Model. Within each type, a number of specific functions are identified and illustrated. In the examples given here, English appears in regular type, Afrikaans in italics, and bold-face type indicates a particular use of a term. English glosses for Afrikaans items appear in small type below each line. T indicates a teacher turn, and S, S1 and S2 indicate learner turns.

\section{Unmarked code switching}

Myers-Scotton (1993a: 114) states that unmarked codeswitching occurs when a speakerhearer makes a certain code choice the unmarked index of the unmarked RO set in the speech exchange. Unmarked code switching is characterised by a continuous pattern of using two or more languages (Myers-Scotton, 1993a: 117).

Such unmarked code switching was observed to fulfil a number of functions. Firstly, as can be seen in (1), such code switching fulfilled a humorous function, when a speaker wanted to elicit a positive response from the hearers. This example of code switching occurred outside the context of the actual lesson, while the teacher and learners were interacting informally on a personal level.
(1) S My maag brom.
my stomach drones
$\mathrm{T} \quad$ Dis my maag grom, nie brom nie.
it's my stomach grumbles not drone not 


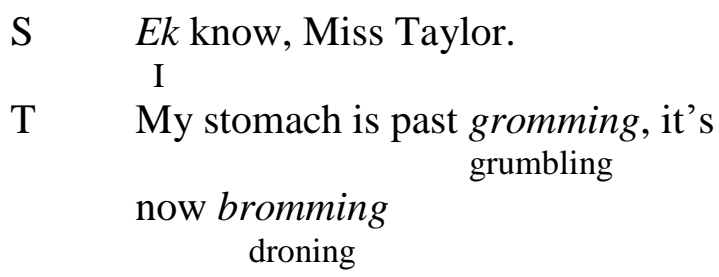

[Everyone in the class laughs]

Unmarked code switching was also observed to fulfil a social function, as an indication of ingroup identity. As is clear from (2), bilingual learners engage in unmarked code switching when using single words from Afrikaans while speaking English, on the assumption that they understand one another.

(2) S1 Guess what Tammy and I are eating now at break - pizza slices! Ha, look at your face.

S2 Will you give me a hap?

bite

S1 Yes man, I will give you a hap.

bite

Code switching as an unmarked choice also functioned to alleviate a word-finding difficulty, when a word from the other language was substituted for a momentarily inaccessible word. An example appears in (3), where once again both teacher and learners understand the meaning of the word in the other language, or indeed do so once the teacher has accessed the target word.

(3) $\mathrm{T}$ We have so many diseases, I don't know what it is called in English but it is ' $n$ ernstige siekte ... um ... pokke, in Afrikaans it's pokke, which killed half of a serious disease small pox in Afrikaans small pox

the society many years ago but even today there's still such sicknesses in the world, like what? Who can name one?

Unmarked codeswitching was also often observed to fulfil an expansion function, where the teacher is sufficiently familiar with her learners and their bilingualism to make an unmarked switch to expand on an explanation (cf. (4) below).

\begin{tabular}{|c|c|}
\hline S & $\begin{array}{l}\text { Is vet ruspers ... um ... object? } \\
\text { fat caterpillars }\end{array}$ \\
\hline $\mathrm{T}$ & $\begin{array}{c}\text { No, who's been vreet-ing? } \\
\text { gorging }\end{array}$ \\
\hline $\mathrm{S}$ & $\begin{array}{l}\text { The vet ruspers. } \\
\text { fat caterpillars }\end{array}$ \\
\hline $\mathrm{T}$ & $\begin{array}{l}J a, \text { the subject. } \\
\text { yes }\end{array}$ \\
\hline S & So what's the object, miss? \\
\hline $\mathrm{T}$ & What has he been eating, eating what? \\
\hline S & $\begin{array}{l}\text { Plantjies. } \\
\text { little plants }\end{array}$ \\
\hline
\end{tabular}


T Plantjies is your object. Grade nines, for subject you say who is doing the work.

Little plants

Who is eating? Vreet is mos eet né? So who is eating? The caterpillars, so the gorge is indeed eat hey?

caterpillars, that is your subject. Vet ruspers is jou onderwerp.

fat caterpillars is your subject

It can thus be concluded that unmarked code switching is an observable reality, and that such code switching may fulfil a variety of functions in the classroom.

\section{Sequential unmarked code switching}

As stated by Myers-Scotton (1993a: 114), sequential unmarked codeswitching occurs when the unmarked RO set changes. This may, for example, occur when the focus or topic of a conversation is altered such that the relationship between speakers is altered. When such a change alters the unmarked RO set, the speaker will switch codes if he/she wishes to index the new unmarked RO set. The Markedness Model predicts that the speaker will choose either to accept or to re-negotiate the new unmarked RO set (Myers-Scotton 1993a: 115).

Sequential unmarked code switching such as that in (5) was observed to function in the teacher's reprimanding of learners. The change from one unmarked code choice to another corresponds to the change in the content and focus of the teacher's utterances, from the topic of work to censure.

T Okay graad nege nou gaan ons 'n klein stukkie werk.

S No, please. No, Miss, please.

grade nines now go us a little piece work

$\mathrm{T} \quad$ Kom ons het nog werk om te merk. come we have still work to mark

$\mathrm{T} \quad$ Bianca why are you walking around?

S Miss, I'm just busy with something.

$\mathrm{T} \quad$ Okay nommer twee-en-veertig, en drie-en-veertig. Open up the books please,

$$
\text { number forty two and forty three }
$$

maak gou oop. Ons het nie tyd gehad om te merk nie. Okay julle I am sure we make quickly open we have not time had to mark not you-plural are on this page forty two and forty three, yes.

Sequential unmarked code switching was also found to fulfil a social function, as in (6), where the topic changes from work to an informal social question, and then back to work. This example also reveals how code switching functions for purposes of humour.

(6) [A learner (Michelle) explains part of a chapter in the English literature book to her classmates]

T Ja, ja goed.

yes yes good

$\mathrm{S} \quad$ And Bruce? [A character in the book]

$\mathrm{T} \quad$ He left, but you can't argue with a drunk person, can you?

S No. 
[Loud chatter and laughing from the learners]

S Miss, what are you doing for Easter?

$\mathrm{T} \quad$ Easter, well setting papers for my grade $12 \mathrm{~s}$, but that is the only work I am going to do, then I am going to relax. But I'm just going to stay at home, I'm not going to go anywhere. Relax.

[More chatter and laughing from the learners]

$\mathrm{T} \quad$ Okay kom ons lees verder, want nou weet ons van dronk mense en wat hulle come we read further because now know we about drunk people and what they doen né, okay. En sy se vir ma is jy nou tevrede? [referring to the book] Sjoe, do hey and she say for mom are you now satisfied wow kom by.

come along

kom by, gou-gou, en sy vra en so met haar tong gevoel dat daar is nou two come along quickly and she asks and so with her tongue felt that there are now missing teeth.

Finally, sequential unmarked code switching was used for purposes of confirmation, as in (7), where both the teacher and the learner (Lolla) wish to have something confirmed, and the conversational setting changes in the process.

S Miss what is $\boldsymbol{k l a - k l a}$ ?

T It's complain-complain.

S No, but I mean ...?

T Manner. Okay guys and girls. Now Lolla, sé gou vir juffrou, we have our say quickly for teacher

mixing bowl, we're going to bake the vanilla word order cake. Okay, subject, now we have to find the subject, number one, that's our first ingredient that we need in our sentence. Which of those words is the subject?

S My pa.

It was noticeable that relatively few instances of sequential unmarked codeswitching occurred. A possible reason for this is that few changes in context occurred in the classes observed, being limited to changes in the content being taught, and occasional changes from content to social topics. Nonetheless, it is clear that sequential unmarked code switching did fulfil certain functions in the classroom interactions observed.

\section{Marked code switching}

A number of examples of marked code switching were recorded, i.e., code switching in order to establish a new RO set as unmarked for the current exchange, as usually occurs only in relatively formal conversational interactions (Myers-Scotton 1993a: 131). One of the functions of such marked code switching was for purposes of clarification, as can be seen in (8), where code switching is used to translate a single word. Such code switching was observed quite often, clearly allowing learners to clarify potential misunderstandings. 
(8) $\mathrm{T}$ This exercise on the board is for next week: taal!

S Juffrou what is aangesien?

language

T It is like because.

S Like because, aangesien?

considering

T Ja, ja like because, and then you have to give a reason. yes yes

$\mathrm{S} \quad$ Is it just positiewe? positives

$\mathrm{T} \quad$ Nee also tien negetiewe, tien negetiewe eienskappe. no ten negatives ten negative characteristics

Another function of marked code switching was that of expansion, where the teacher code switched longer phrases in expanding explanations to ensure understanding by the learners, as in (9).

(9) $\mathrm{T}$ Okay there is a little word there, two words $\boldsymbol{k l a - k l a}$, wat is kla-kla, julle, moan-moan what is moan-moan, you-plural wat is kla? Finished? Okay klaar, with an $\mathbf{r}$ is finished, maar kla? what is moan finished moan

S1 Quickly, quick-quick.

S2 Moan, it's moaning.

$\mathrm{T} \quad$ Nee, it's moaning, as jy kla dan moan jy. Julle weet almal hoe om te kla, Nan, no when you moan then you You know all how to moan Zoë? Kla-kla, what does that tell you, complain-complain? What? Does that moan-moan

say where? Does that say when? Does that say how? How is father digging in the garden?

S Moaning, moaning.

$\mathrm{T} \quad$ Moaning, moaning.

$\mathrm{S} \quad$ And groaning.

$\mathrm{T} \quad$ So $k$ la-kla is manner.

moan-moan

Marked code switching also occurred when the teacher displayed anger in reprimanding the learners, as can be seen in (10). The teacher's use of the marked choice appears to be an attempt to emphasise her desire to be taken seriously.

(10) $\mathrm{T}$ Okay, have you all got one now? Right, if we read from the top, it says a very important part of choosing a career is working out what would suit your own interests and abilities. The average person works forty years before retiring. Okay, so the average person goes to school for how many years?

[No answer comes from the learners]

T Kom nou julle.

come now you-plural

S Um, twelve. 
$\mathrm{T} \quad$ Twelve years. Just think, if you hate every minute of twelve years, think how nice it's going to be to hate forty years, not nice hey? Okay, so that's why we need to be very careful in choosing what you want to do one day.

Another function fulfilled by marked code switching in the classes observed was humour. Both the teachers and the learners were observed to use codeswitching as a way to get a positive and humorous response, as in (11). This is an example of marked code switching because it occurs during the formal teaching part of a lesson, rather than during an informal conversation on a more personal level (cf. the examples in (1) and (6)). In the case of the example in (11), neither the student nor the teacher is aiming to be sociable, yet the switch still elicits a humorous response.

(11) T Hoofstuk ses, nommer een tot tien.

S Oh. chapter six number one to ten

$\mathrm{T} \quad$ Okay, ons gaan nie nou hare doen nie, lê, of op jou arms, want jy is te moeg we go not now hair do not lie either on your arms because you are too tired om te werk en jy werk vanmiddag waanneer ons gaan naweek hou. Die ander to work and you work this afternoon when we go week-end hold the other ouens gebruik die tyd. guys use the time

S Asseblief kan Melissa stay with me? [Melissa is playing with Becky's hair] please can

T Hoekom? why

S Because it feels so nice, it makes me go to sleep.

$\mathrm{T} \quad$ Nee, maar jy gaan omval. Kom sit dan hierso. no but you go fall over come sit then here

[Everyone in the class laughs]

Marked code switching also fulfilled the social function of identity marking, as in (12), where the learner S2 switches to Afrikaans with an expression which is understood by her classmate but not by the teacher, who is a visiting student teacher from the United States of America. This is an example of marked switching; although the context is somewhat relaxed, the teacher and the learners are not in the same in-group, due to differences in age, L1, ethnic identity, and culture.

(12) S1 Miss Shannon, have you ever been to Table Mountain?

$\mathrm{T} \quad$ Yes I went yesterday.

S2 Did you enjoy it? I have never been.

T Really?

S1 Me either, but we live here.

S2 I know, should we go together?

S1 Yes then we can bungi jump off the cable cart.

S2 Yes that would be so kwaai né?

harsh hey

Finally, marked code switching was observed to function for purposes of confirmation. In the example in (13), the teacher switches in an effort to confirm that the learner has understood, 
and the learner (S1, Johanellie, whose L1 is Afrikaans) in turn switches in an effort to confirm her language choice.

(13) T Okay, mooi, nog iets, Johanellie? Nee? Okay, Michelle, jy kan maar. Okay, ja toemaar, ja, Johanellie?

good something else no you can just yes

never mind yes

[Johanellie shakes her head]

S1 Sy het ... um...

$\mathrm{T} \quad$ Sê maar in Engels dan verstaan almal.

say just in English then understand everyone

S1 Um ...

S2 Say it in Afrikaans.

S1 She arrives with her crutches.

$\mathrm{T} \quad$ Wil jy dit in Afrikaans vir ons sê nie? Jy kan probeer, ek weet jy kan. want you it in Afrikaans for us say not you can try I know you can

S1 Maar ek wil nie.

but I want not

$\mathrm{T} \quad$ Okay, jy wil nie? Okay, jy hoef nie. Okay, Michelle. you want not you need not

As in the cases of unmarked and sequential unmarked code switching, it is evident that instances of marked code switching are clearly identifiable, and that such code switches serve specific functions in the classrooms observed.

\section{Exploratory code switching}

No examples of exploratory codeswitching were recorded in the classes observed. Exploratory codeswitching usually occurs when an unmarked code choice is not clear, to make alternative exploratory choices when speaker-hearers themselves are unsure of the expected communicative intent (Myers-Scotton, 1993a: 142). According to Kieswetter (1997: 16), codeswitching to make an exploratory choice occurs momentarily, as strangers explore code choices within a new and uncertain situation or interaction. In the context of the familiar classroom environment of the present study, no new, strange or uncertain situations arose, which may be the reason for the lack of exploratory code switching.

The analysis of the data given above offers direct evidence in support of three of the four types of code switching identified on the basis of Myers-Scotton's (1993a) Markedness Model, namely unmarked, sequential unmarked, and marked code switching. It is further assumed that exploratory code switching would very likely be observed in other contexts. It may thus be concluded that the Markedness Model offers a useful framework for the analysis of code switching data.

Furthermore, the results of the present study clearly indicate that code switching between English and Afrikaans fulfils particular functions in the classrooms observed, and it may be assumed that code switching between other language pairs fulfils these and possibly other functions in multilingual classrooms in general. Some of the functions identified, such as clarification, confirmation, and expansion, may be seen to aid teachers and learners in attaining academic goals. Other functions, such as identity marking and humour, may be seen 
to fulfil a social function. It may be concluded that code switching may be used as a communicative tool by both teachers and learners in multilingual classrooms, and that it ought not to be regarded either as detrimental to the academic enterprise, or as socially unacceptable.

Acknowledgement: This material is based on work supported by the National Research Foundation under grant number NRF GUN 2069846. Any opinion, findings and conclusions or recommendations expressed in this material are those of the author and do not necessarily reflect the views of the National Research Foundation.

\section{ENDNOTES}

${ }^{1}$ Cf. Stone (1995) and McCormick (2002) with regard to this mixed code, characteristic of certain areas of the Western Cape.

${ }^{2}$ Besides her work on sociolinguistic aspects of code switching, Myers-Scotton (1993b) also considers grammatical aspects of code switching, in terms of the so-called "Matrix Language Frame" model (cf. also Jake, Myers-Scotton and Gross 2002). The present study, however, focuses only on the sociolinguistic aspects and applies the Markedness Model.

\section{REFERENCES}

ADENDORFF, R. 1993. Code-switching amongst Zulu-speaking teachers and their pupils: its functions and implications for teacher education. Southern African Journal of Applied Language Studies, 2 (1): 3-26.

GRICE, HP. 1975. Logic and conversation. In Cole, P \& J Morgan (eds), Syntax and semantics 3: Pragmatics. New York: Academic Press.

JAKE, JL, C Myers-Scotton \& S Gross. 2002. Making a minimalist approach to codeswitching work: Adding the matrix language. Bilingualism. Language and Cognition 5(1): 69-91.

KIESWETTER, A. 1995. Code-switching among African high school pupils. University of the Witwatersrand Occasional Papers in Linguistics, 1.

$\begin{array}{llllll}\text { LANGUAGE IN } & \text { EDUCATION } & \text { POLICY } & \text { (South Africa). }\end{array}$ http://www.polity.org.za/html/ govdocs/policy/edulangpolicy.html. Accessed on 8 August 2006.

LAWRENCE, D. 1999. Kodewisseling: Engels in Afrikaans - ' $n$ instrument tot effektiewe kommunikasie. Journal for Language Teaching, 33 (3): 265-274.

LAWRENCE, D. 2001. Afrikaans-Engels kodewisseling: 'n instrument vir die effektiewe hantering van multitalige en mutikulturele situasies. Paper delivered at the National Conference on Challenges for language Teaching in the New Millennium, University of Potchefstroom.

MCCORMICK, K. 2002. Language in Cape Town's District Six. Oxford: Oxford University Press. 
MUYSKEN, P. 1995. Code-switching and grammatical theory. In Milroy, L and P Muysken (eds.) One speaker, two languages. Cambridge: Cambridge University Press. 177-197.

MYERS-SCOTTON, C. 1993a. Social motivations for codeswitching. Evidence from Africa. Oxford: Clarendon Press.

MYERS-SCOTTON, C. 1993b. Dueling languages. Grammatical structure in codeswitching. Oxford: Clarendon Press.

MYERS-SCOTTON, C. 1998. A theoretical introduction to the markedness model. In MyersScotton, C (ed), Codes and consequences. Choosing linguistic varieties. New York and Oxford: Oxford University Press.

NCOKO, SOS, R OSMAN \& K COCKROFT. 2000. Codeswitching among multilingual learners in primary schools in South Africa: An exploratory study. International Journal of Bilingual Education and Bilingualism, 3 (4): 225-241.

RAMSAY-BRIJBALL, M. 2003. A sociolinguistic investigation of code-switching patterns among Zulu L1 speakers at the University of Durban-Westville. Unpublished PhD dissertation, University of Natal, Durban.

RAMSAY-BRIJBALL, M. 2004. Exploring identity through code-switching: A poststructuralist approach. Alternation 11(2): 144-164.

SETATI, M, J ADLER, Y REED \& A BAPOO. 2002. Incomplete journeys: Code-switching and other language practices in mathematics, science and English language classrooms in South Africa. Language and Education, 16 (2): 128-149.

STONE, G. 1995. The lexicon and sociolinguistic codes of the working-class Afrikaansspeaking Cape Peninsula coloured community. In Mesthrie, R (ed.) Language and social history. Studies in South African sociolinguistics. Cape Town and Johannesburg: David Phillips. 277-290.

\section{BIOGRAPHIC NOTE}

Suzanne Rose is a student completing her MPhil in Intercultural Communication in the Department of General Linguistics at Stellenbosch University. The research reported forms part of the degree requirements.

Ondene van Dulm is a lecturer in the Department of General Linguistics at Stellenbosch University, and is responsible for teaching at undergraduate and postgraduate level on sociolinguistics and psycholinguistics, among other topics. Her doctoral research focuses on structural aspects of English-Afrikaans intrasentential code switching, under the supervision of Prof Pieter Muysken of Radboud Universiteit Nijmegen, the Netherlands. Email: ovd@sun.ac.za 